\title{
Regional Entrepreneurial Capacity
}

\author{
Elena Rozhdestvenskaia ${ }^{1 *}$ \\ ${ }^{1}$ Tomsk State University, 634050, Lenin str., 30, Russia
}

\begin{abstract}
The article aims to study the category of "entrepreneurial capacity" and to develop a system for assessing entrepreneurial capacity at the regional level. The system of economic indicators was developed to assess the entrepreneurial capacity of the region based on the dialectics of the general and special leading concepts. To test proposed method author has carried out a trial assessment using the case of the Tomsk region.
\end{abstract}

Key words: entrepreneurship, resource capacity, business planning, institutional economics, COVID-2019

\section{Introduction}

Current crisis of the economic system shows rejections on supply and demand [1], which forced developing anti-crisis measures as a priority to economic development [2]. The Russian Government has amended a number of National projects in key areas of socioeconomic development until 2024, including updated projects in the field of development and support of entrepreneurship. This project raises issues not only of financing and supporting entrepreneurial structures, but also of promoting a positive attitude in society towards entrepreneurs and business representatives. At the federal level formed the need to establish a socio-cultural business environment along with traditional measures of support and state assistance, especially in sectors affected by COVID-2019. This article is devoted to the problem of accumulation and realization of entrepreneurial capacity with a focus on the regions (on the case of the Tomsk region). In the scientific literature, entrepreneurship as an economic category defines multisided; a unified approach to determination has not developed yet. The entrepreneurial capacity, including its regional level, is becoming an object of study for foreign and Russian authors, but the approaches are even more pluralistic. In this paper, tend an issue to the analysis of well-known approaches to the study of entrepreneurial potential and the development of a common solution that allows advancement in the evolutionary theory of entrepreneurship, which is not established as an independent industry at the present stage. The purpose of this article is to define the category of "entrepreneurial capacity" and propose a system of indicators for its assessment at the regional level.

\footnotetext{
* Corresponding author: elena.rojdestvenskaya@gmail.com
} 


\section{Research methods and taxonomy of "entrepreneurial capacity"}

Author applies analysis of existing definitions and categories, carries out a content analysis of scientometric databases Web of Knowledge, Elibrary, Google Scholar to define the category "entrepreneurial capacity". As a result, the system of economic indicators has developed to assess the entrepreneurial capacity of the region based on the dialectics of the general and special leading concepts of the individual components. In this paper author makes a trial assessment of the entrepreneurial capacity using the example of the Tomsk region as a test of the proposed method.

Entrepreneurship studies often begin with attempts to determine the theoretical field and main categories. The evolution of scientific views most often begins with a review of the works of R. Cantillon and J. Schumpeter, but, unfortunately, in their works, we can find indirect references to the formation of a new scientific field, the category of "entrepreneurship" is considered in the context of economic activity.

In the general case, there are two common approaches to develop an "entrepreneurial" research field [1]. On the one hand, tools and mechanisms are developed to predict the dynamics and success of the business process (positivistic approach) [2], on the other hand, models and variables are proposed to explain and understand the entrepreneurial process and the features of its development (constructivist approach). Both tasks are not mutually exclusive, but they aim at a deep understanding of the essence and content of the phenomenon. We should emphasize that the foreign tradition of research often relies on a positivistic approach, focusing on tools for predicting the outcome of the "process of creative destruction" [3]. They use the concepts of the entrepreneurial ecosystem and network organizational capacity as a factor in the future positive dynamics of the development of entrepreneurship, especially small and medium-sized businesses. In Russian-language literature, they often turn to the problem on the basis of the prevalence of the constructivist approach with attempts to scientifically determine the essence of the phenomenon, starting with the founders of the theory of entrepreneurship - Cantillon, Turgot, Say and Schumpeter [4] [5] [6] [7]. In this study, we will continue the tradition of scientific research, which are focusing mainly on determining the essence of the phenomenon and assessing its scale.

In the general case, we can say that some scientists associate an entrepreneurial resource with special personality traits and individual abilities [8] [9] [10]. In other words, entrepreneurial capacity understands as part of the labor capacity. In addition, special attention is paid to the problem of differentiating the abilities of managers as professionals and entrepreneurs, the requirements for entrepreneurial abilities are decomposed and tightened in dynamics [11] [12]. The main indicators used are the share of employees in small and medium-sized businesses, the share of small and medium-sized enterprises in the total volume of economic entities, the number of jobs created (including highly productive in the context of innovative entrepreneurship).

It should be distinguished another group of scientists who consider the business process in the context of external and internal environment [1] [13]. Entrepreneurial capacity is determined by the totality of environmental opportunities - the infrastructure to support entrepreneurship and business, the development of the entrepreneurial culture of society [14] [15], society involvement in creating new value. Moreover, the issues of generating new value and macro/ microenvironment are separately considered. In this approach, the entrepreneurial process becomes inseparable from local socio-economic conditions. Entrepreneurial capacity has considered from the perspective of local opportunities for implementing entrepreneurial intentions. [16], the combination of abilities and qualifications has taken as an endogenous variable along with institutional indicators of the development of the entrepreneurial ecosystem [17]. Thus, there is a multidimensionality in determining the category of entrepreneurial capacity, each researcher contributes, but in general terms, 
two main approaches to define entrepreneurial capacity (1) as a personality traits: special immanent properties of the individual; (2) as an ecosystem features: set of conditions for doing business. Recent studies tend to share entrepreneurial intentions [18] may use GEM indicator as an indicator of entrepreneurial capacity) and entrepreneurial capacity, dividing the phase of the entrepreneurial process into "pre-action" (up to the moment of action) and "active" (the emergence of entrepreneurial activity) [19].

Thus, one should consider the entrepreneurial capacity in the context of practical activities, realized intentions and organized economic activities.

\section{Results}

\subsection{Entrepreneurial capacity as an economic category}

The systematization of known solutions allows us to offer a definition of the category under study. Entrepreneurial capacity is a socio-economically determined set of opportunities for implementing entrepreneurial abilities. This definition takes into account the three main components of the entrepreneurial ecosystem: labour capacity, social environment and institutional (organizational) frameworks (Fig. 1).

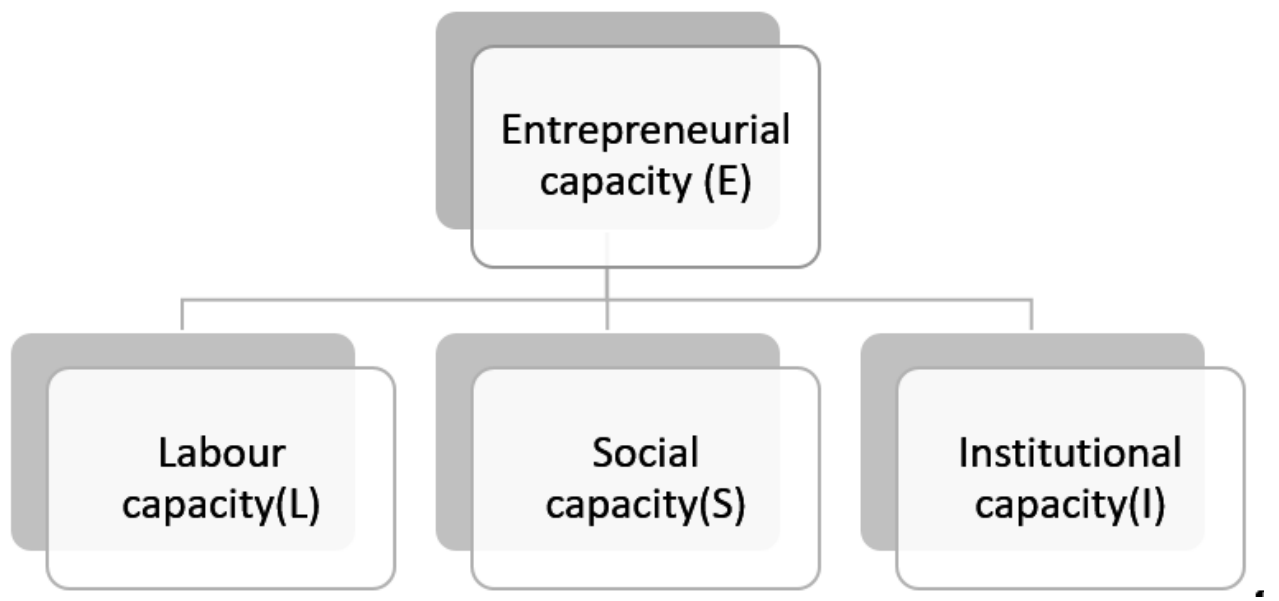

Fig. 1. Correlations of the category "entrepreneurial capacity" with the economic resources

In the scientific literature, attempts have already been made to develop a method for assessing entrepreneurial potential [20] [21] [5], based on the resource approach and the method of weighted average assessment of the constituent elements.

Table 1. The system of indicators for assessing entrepreneurial capacity.

\begin{tabular}{|c|c|c|c|}
\hline Domain & Criteria & Indicator & Symbol \\
\hline $\begin{array}{c}\text { Entrepreneurial skills and } \\
\text { professional competencies }\end{array}$ & Labour capacity & $\begin{array}{c}\text { Labor force } \\
\text { qualification rate }\end{array}$ & $\mathrm{L}$ \\
\hline $\begin{array}{c}\text { Social environment and } \\
\text { entrepreneurial culture of society }\end{array}$ & Social capacity & $\begin{array}{c}\text { Entrepreneurial } \\
\text { culture rate }\end{array}$ & $\mathrm{S}$ \\
\hline $\begin{array}{c}\text { Enterprise Support Infrastructure } \\
\text { and Institutional Development }\end{array}$ & $\begin{array}{c}\text { Institutional } \\
\text { capacity }\end{array}$ & Doing business rate & $\mathrm{I}$ \\
\hline
\end{tabular}

Source: compiled by the author based on [1] [21] [5] 
Thus, using index method we gain the formula for estimating region's entrepreneurial capacity by three main domains:

$$
E=\sqrt{ }(0.33 L+0.33 S+0.33 I)
$$

where is $\mathrm{E}$ - entrepreneurial capacity;

L - Labor capacity;

S - social capacity;

I - institutional capacity.

\subsection{Testing the system of indicators for assessing entrepreneurial capacity on the case of the Tomsk region}

Based on rating assessments for formula 1, we could use a scale to interpret the results. This way, results (1), which are below 0.75 , reflect region fragility for negative factors. Results (2), which are from 0.75 to 1.0 , reflect region entrepreneurial capacity as a factor of resilience. Other results (3) reflect region resilience for negative factors in long-term.

Using the data of the Tomsk branch of Federal statistics and formula 1, we could calculate the size of the entrepreneurial capacity of the region, using the case of the Tomsk region. Official statistics, of course, do not collect these indicators in the context and method of aggregation that we require. To test the model, we use ready-made indicators that meet the selection criteria (Table 1). The rate of qualification of the workforce is logical to calculate as the ratio of the number of people trained in programs of various levels to the total number of labour. The labour force in Tomsk and the Tomsk region as of June 2020 has estimated at 540 thousand people. In official statistics, there is an opportunity to track the number of graduates of educational programs of different levels; so, we could calculate the qualification of the workforce by comparing the data of different reporting forms. The entrepreneurial culture is assessed by researchers differently; at the macro level, researchers use indicators of involvement in entrepreneurial processes as an indicator of the number of entrepreneurial actions [22] [20]. Then it is quite possible to use the indicator of the number of people employed in the field of SMEs in the region, since, on the one hand, it also reflects the scale of the phenomenon in society, on the other hand, it shows the degree of personal interest of the regional society in the development of entrepreneurship. The rate of business conditions has calculated based on the data of the passport of the investment climate of Tomsk Region PwC for 2017 (URL: http://unitomsk.ru/upload/putevoditel_investora_po_tomskoy_oblasti.pdf). All data for calculating the assessment of entrepreneurial capacity of the Tomsk region has presented in Table 2 .

Table 2. Dataset for calculating the entrepreneurial capacity of the Tomsk region

\begin{tabular}{|c|c|c|}
\hline Indicator & $\begin{array}{c}\text { Indicator value } \\
\mathbf{2 0 1 7} \text { year }\end{array}$ & Symbol \\
\hline Labour force qualification rate & 0.0642 & $\mathrm{~L}$ \\
\hline Entrepreneurial culture rate & 0.26 & $\mathrm{~S}$ \\
\hline Doing business rate & 0.46 & $\mathrm{I}$ \\
\hline
\end{tabular}

Source: compiled by the author based on [25] [26]

Applying formula 1 to the calculated data for each indicator, we obtain the weighted average assessment of the entrepreneurial capacity of the Tomsk region equal to 0.51 or $50 \%$.

Of course, for a more accurate calculation, we should launch a system of indicators and data collection, using the data of longitudinal studies of the Russian and foreign regions to 
verify and further test the proposed model. In the future, we propose to consider the entrepreneurial potential of the region as a value that could be estimating quantified and qualitatively, but also could be predicted in the medium and long term.

\section{Conclusion}

As a result, this paper has defined entrepreneurial capacity as a combination of three elements - labor capacity, social environment and institutional (organizational) frameworks. This approach made it possible to select assessment criteria taking into account the multidimensionality of the phenomenon itself and to propose an indicator for assessing the entrepreneurial potential of the region. Based on official statistics (Tomsk stat), with great assumptions, the proposed methodology was tested on the case of the Tomsk region. These studies suggest that the accumulated entrepreneurial capacity in the region has the power to support the economy in conditions of instability of supply and demand under the influence of external shocks. A value of 0.51 indicates a low resistance of the entrepreneurial capacity to the effects of negative shocks such as, for example, COVID-2019.

It is important to notice that estimates of entrepreneurial capacity in the Tomsk Region do not extrapolate to the Russian economy as a whole. The region is characterized by a high share of the science and education sector (up to 25\% of GRP); by high-developed entrepreneurship support infrastructure (up to 12 business incubators, up to 24 business support centres, up to 20 industrial infrastructure and support centres); and by a favourable investment climate (14th place 30 Russian cities included in the Doing Business index). The high concentration of universities in the region (6 universities) and the obtained data on the assessment of entrepreneurial capacity in the region confirm the hypothesis of a high correlation of these two factors and their significance for regional economic development [25].

Despite the accumulation of entrepreneurial capacity, since the beginning of 2020 in the region there has been a negative dynamics of GRP growth rates and a negative growth in the number of enterprises and organizations. The "double shock" had a negative impact on the regional economic system; the slow recovery of the regional economy will confirm the research hypothesis.

The value of the research results reflects the possibility of assessing the entrepreneurial potential of the region to analyse the effectiveness of government measures to support business and entrepreneurship. The research model allows developing independent assessments based on panel data from the region, which lays the foundation for a future system for monitoring business activity and entrepreneurial potential as part of the implementation of systemic state support measures. We face new challenges of adverse external shocks (coronavirus, economic crisis) and effectiveness of budget expenses problem becomes more and more in demand.

Acknowledgments. The study was supported by the Russian Science Foundation as part of the research project "Institutions to unlock the untapped resource potential of the older generation in an aging economy" (project No. 19-18-00300).

\section{References}

1. V. May, Double shock: the economic crisis due to the pandemic may not go according to the scenario for which countries are preparing, Forbes, (2020) 
2. V. Pechatkin, The formation and development of the digital economy in Russia as a strategic priority for the development of territories in the context of pandemics Innovation Economy Issues, 10(2), 837-848, (2020) [In Russian]

3. C. Bruyat, P.-A. Julien, Defining the field of research in entrepreneurship, J. Bus. Ventur. 16, 165-180 (2000)

4. K. Latif, A. Nazeer, F. Shahzad, M. Ullah, M. Imranullah, U. Sahibzada, Impact of entrepreneurial leadership on project success: mediating role of knowledge management processes, Leadership. Org. Dev. J. 41(2), 237-256 (2020)

5. T. Liu, L. Tang, Open innovation from the perspective embedding: knowledge evolution and development trend (2020)

6. I. Cheplayeva, (In Russian) Thesis of PhD in Economics: 08.00.07, Saratov, p. 168, (1999)

7. I. Vasylieva, Entrepreneurial potential and its role in ensuring the sustainable functioning of a higher educational institution in market conditions, Russian business, 10(7), 130-136 (2009) [In Russian]

8. S. Egorihinaa, Entrepreneurial potential of the population of the region, Territory Development Problems, pp. 42-50 (2011) [In Russian]

9. O. Toporkov, The evolutionary essence of entrepreneurship as the basis for the development of new mechanisms for activating agribusiness, Economics and Entrepreneurship, 2(115), 704-710 (2020) [In Russian]

10. G. Minov, Theoretical aspects in the application of the concept of "entrepreneurial potential" in modern conditions, Modern Economy: Problems, Trends, Prospects, 5, 1-4 (2011) [In Russian]

11. O. Drovyashina, Entrepreneurial potential of Russia, Walkway of science, 1(17), 227231 (2018) [In Russian]

12. E. Lichanos, About the concept of "entrepreneurial potential" SWorld, URL: https://www.sworld.com.ua/konfer38/123.pdf, (2015) [In Russian]

13. S. Nevdaha, Entrepreneurial potential of an enterprise: concept and structure Vestnik TSU, 10(66), 441-449 (2008) [In Russian]

14. C. Chen, P. Greene, A. Crick, Does entrepreneurial self-efficacy distinguish entrepreneurs from managers? J. Bus. Ventur. 13, 295-316 (1988)

15. K. Bogatyreva, G. Shirokova, From Entrepreneurial Aspirations to Founding a Foresight and STI Governance 11(3), 25-36 (2017)

16. S. Dwarampudi, The Role of Culture on Entrepreneurship Development, LinkedIn, http://www.slideshare.net/srinivasreddydwarampudi/the-role-of-culture-onentrepreneurship-development, (2014)

17. J. Li, R. P. Lee, Can Knowledge Transfer within MNCs Hurt Subsidiary, Journal of World Business, 50(4), 663-673 (2014)

18. M. Socci, D. Clarke, A. Principi, Active Aging: Social Entrepreneuring in Local Communities of Five European Countries, Int. J. Env. Res. Pub. He. 17, 7 (2020)

19. J. Lampe, P. Kraft, A. Bausch, Mapping the Field of Research on Entrepreneurial Organizations (1937-2016): A Bibliometric Analysis and Research Agenda, Entrep. Theory Pract. 44 (4), 784-816 (2020)

20. F. Vega-Gomez, F. Gonzalez, A. Mera, J. Perez-Mayo, Antecedents of Entrepreneurial Skills and Their Influence on the Entrepreneurial Intention of Academics, Sage Open, 10(2) (2020) 
21. M. Gonzalez-Lopez, M. Perez-Lopez, L. Rodriguez-Ariza, From potential to early nascent entrepreneurship: the role of entrepreneurial competencies, Int. Enterpren. Manag. J. DOI: 10.1007/s11365-020-00658-x (2020)

22. D. Isenberg, The Entrepreneurship Ecosystem Strategy as a New Paradigm: Principles for Cultivating Entrepreneurship, The Babson Entrepreneurship Ecosystem Project (2011)

23. L. Gilemhanova, Ju.Zapol'skih, Entrepreneurial potential, NovaInfo, 46, 2 (2016) [In Russian]

24. W. Gather, Who is entrepreneur? is the wrong question, American Journal of Small Business, 12(4), 11-32 (1988)

25. Tomskstat dataset. URL: https://tmsk.gks.ru/.

26. PwC Investment climate passport data (Tomsk Region). URL: http://unitomsk.ru/upload/putevoditel_investora_po_tomskoy_oblasti.pdf.

27. T. Brekke, What Do We Know about the University Contribution to Regional Economic Development? A Conceptual Framework, Int. Reg. Sci. Rev., 1-33 (2020) DOI: $10.1177 / 0160017620909538$ 